\title{
Behaviors to Promote Healthy Eating and Physical Activity: Training Staff for After School Programs
}

\author{
Kimberly Nerud ${ }^{1 *}$ and Matt Steiner ${ }^{2}$ \\ ${ }^{1}$ Department of Nursing, University of South Dakota, USA \\ ${ }^{2}$ Boys and Girls Club of Watertown, USA
}

Submission: January 25, 2018; Published: March 09, 2018

*Corresponding author: Kimberly Nerud, Department of Nursing, University of South Dakota School of Health Sciences 1400 W $22^{\text {nd }}$ St, Sioux Falls, SD 57105, USA, Tel: 605-357-1551; Fax: 605-357-1528; Email: kimberly.nerud@usd.edu

\begin{abstract}
Escalating obesity rates among children across the nation has prompted interest in investigating the role of after school programs in the promotion of healthy eating and physical activity among participating children. This approach facilitates intervention programs that can be rooted in daily routines by frontline staff. Children need positive role models, the work could be a challenging process and will require motivating staff.
\end{abstract}

Keywords: Childhood obesity; After school program; Role model

\section{Introduction}

Childhood obesity is among the leading health concerns in the United States. The prevalence of childhood obesity in the United States has reached epidemic proportions, with nearly one third of children overweight or obese [1]. Current estimates indicate that in the United States more than 20\% of children aged two to five years are already overweight or obese [2]. Even more troubling is that overweight developed in early childhood is likely to persist through adolescence and adulthood [3,4]. Now more than ever the role of after-school programs (ASP) can play an important role to support health and wellness of children and adolescence [5]. The afterschool field has stepped up its focus and has been called upon to promote healthy eating and physical activity (HEPA) to the children they serve. These HEPA standards outline key behaviors that frontline staff model [6].

An estimated 8.4 million children attend ASP [7]. However, staff need guidance to become agents of change. Expecting ASP staff to be role models in keeping the family lifestyle healthy takes for granted that the staff have the knowledge to fulfill this role [3]. Childhood is an important time for the prevention of overweight and obesity, as many dietary and physical activity behaviors are learned during this period and carried into adulthood $[8,9]$.
As children grow, individual dietary choices and perceptions of activity become critical as children grow and gain more autonomy $[10,7]$. The majority of children in the United States consume diets that do not meet the United States Department of Agriculture 2015 Dietary Guidelines for Americans [11], nor do they achieve adequate levels of daily physical activity [12]. Staff engagement of HEPA promoting behaviors could potentially have positive effects on health outcomes of the children in ASP.

Recent national directives called for investigations to identify effective approaches to sustain and integrate childhood obesity interventions in health, education, and care systems taking into consideration measures of equity and long-term impact [13-15]. Findings from studies involving multi-component interventions indicate that it is possible to achieve multiple health-promoting changes in school children [16-18]. However, studies are limited by lack of readiness of both leaders and staff to implement these interventions; it remains unclear which component(s) has the most impact on behavior change [14].

\section{Discussion}

This intervention is an example of this directive was supported by The Boys \& Girls Club of America from the Midwest 
Region who partnered with the Centers for Disease Control to provide training to selected staff to teach them how to train other staff and faculty members on implementing HEPA in their ASP and to other surrounding community programs. By using role modeling, peer to peer, and fun activities in their after school programming staff could create healthy norms that young kids could develop, and it would bridge the gap between what children may not be receiving at home, or outside of the schools and these after school programs.

The success of HEPA standards is dependent on the staff's willingness and acceptability of self-refection of their own feelings of healthy eating and physical activity habits. Involvement in service-learning programs for staff such as HEPA can also serve as socializing agents as staff acquire the beliefs and knowledge about the role of frontline staff [19]. Staff need to have an accurate understanding of health nutrition before this understanding can be passed on the ASP participants. Research supports the premise that children who receive adult supervision and additional learning opportunities outside of the traditional school day are less likely to engage in unhealthy behaviors [20].

\section{Conclusion}

This work can be challenging, so organizations should start the discussion on HEPA standards by encouraging confident youth development and positive staff role modeling. Strategies for adaptation and implementation in ASPs must be a collaborative effort of administration, staff, and parents. Changing environments is a challenging process and requires role models within the environment to champion the cause. However, future training to help promote improvements in knowledge, attitudes, and behavioral health intentions as well as personal health behaviors for other topic areas related to obesity for ASP staff are warranted.

\section{References}

1. Steele MM, Steele RC, Cushing CC (2012) Weighing the pros and cons in family-based pediatric obesity intervention: Parent and child decisional balance as a predictor of child outcomes. Children's Health Care 41(1): 43-55.

2. Ward DS, Vaughn AE, Bangdiwala SI, Campbell M, Jones DJ, et al. (2011) Integrating a family-focused approach into child obesity prevention: Rationale and design for the My Parenting SOS study randomized control trail. BMC Public Health 11: 431.

3. James K, Connelly C, Garcia L, Mareno N, Baietto J (2010) Ways to enhance children's activity and nutrition: A pilot project with Latina mothers. J Spec Pediatr Nurs 15(4): 292-300.

4. Bender M, Nader P, Kennedy C, Gahagan S (2013) A culturally appropriate intervention to improve health behaviors in Hispanic mother-child dyads. Child Obes 9(2): 157-163.

5. Kids on the Move: Afterschool programs promoting healthy eating and physical activity.

6. Weaver RG, Beets MW, Saunders RP, Beighie AB, Webster C (2014) A comprehensive professional development training's effect on afterschool program staff behaviors to promote healthy eating and physical activity. J Public Health Manag Pract 20(4): E6-E14.

7. Gesell SB, Sommer EC, Lambert EW, Vides de Andrade AR, Whitaker L, et al. (2013) Comparative effectiveness of after-school programs to increase physical activity. Journal of Obesity 2013(2013): 8.

8. Hodges EA (2003) A primer on early childhood obesity and parental influences. Pediatr Nurs 29(1): 13-16.

9. Kinra S, NelderR, Lewendon G (2000) Deprivation and childhood obesity: A cross sectional study of 20,973 children in Plymouth, United Kingdom. J Epidemiol Community Health 54(6): 456-460.

10. Branscum P, Housley A, Bhochhibhoya A, Hayes L (2016) A formative evaluation of Healthy Heroes: A photo comic book-social cognitive theory based obesity preventions program. J Health Education Teaching 7(1): 52-63.

11. United States Department of Health and Human Services (USDHHS) U.S. Department of Agriculture (2016) 2015 Dietary Guidelines for Americans.

12. Davison K, Jurlowski J, Li K, Kranz S, Laweon H (2013) A childhood obesity intervention developed by families for families: Results for a pilot study. Int J Behav Nutr Phys Act 10: 3.

13. NHLBI (2013) We can! Ways to enhance children's activity and nutrition.

14. Waters E, Silva Sanigorski A, Burford BJ, Campbell KJ, Gao Y, et al. (2011) Interventions for preventing obesity in children. Cochran Database of Systematic Reviews 12: 1-203.

15. Rhee K, De Lago C, Arscott Mills T, Mehta S, Kyrsko, et al. (2005) Factors associated with parental readiness to make changes for overweight children. Pediatrics 116(1): e94-e101.

16. Nerud K, Samra H (2016) Make a Move: An intervention to reduce childhood obesity. J Sch Nurs 33(3): 205-213.

17. Jones A, Parkinson K, Drewett R, Hyland R, Pearce M, et al. (2011) Parental perceptions of weight status on children: The Gateshead Millennium Study. Int J Obes 35(7): 953-962.

18. McAlister A, Perry C, Parcel G (2008) How individuals, environments, and health behaviors interact: Social cognitive theory. In: Glanz K, Rimer B, Viswanath K (Eds.), Health behavior and health education: Theory, research, and practice ( $4^{\text {th }}$ edn) Jossey-Bass, San Francisco, CA, USA, pp: 169-188.

19. Gaudreault KL, Shiver V, Kinder C, Guseman E (2016) Healthy Pokes: After-school education and mentoring to enhance child health. J Phys Educ Recreation Dance 87(1): 38-43.

20. Clark E, Buswell SA, Morgitan J, Compton L, Westendorf G, et al. (2014) School-sponsored before, after and extended school year programs: The role of the school nurse. 
This work is licensed under Creative Commons Attribution 4.0 Licens

DOI: 10.19080/CRDOJ.2018.06.555683
Your next submission with Juniper Publishers will reach you the below assets

- Quality Editorial service

- Swift Peer Review

- Reprints availability

- E-prints Service

- Manuscript Podcast for convenient understanding

- Global attainment for your research

- Manuscript accessibility in different formats

( Pdf, E-pub, Full Text, Audio)

- Unceasing customer service

Track the below URL for one-step submission https://juniperpublishers.com/online-submission.php 